\title{
GENERATION Y TRENDS IN CHOOSING AN EMPLOYER: IMPACT OF EMPLOYER BRANDING TOWARD INTENTION TO APPLY IN
} E-COMMERCE COMPANIES IN INDONESIA

\author{
DEDIEK TRI KURNIAWAN \\ Department of Management, University of Indonesia Salemba Jakarta, Indonesia, fully sponsored by
} LPDP(Lembaga Pengelola Dana Pendidikan), Indonesia

\begin{abstract}
While a growing startup in Indonesia, large companies in Indonesia are rapidly responding to changes to compete against startups in the labor market. The increasing foreign investment in IT Startup Company in Indonesia opened more job opportunities in the sector. E-commerce is companies that receive the highest foreign investment in Indonesia that possible expand more. Of course, the startup company becomes the new player in obtaining a potential candidate in the labor market. The objective of this study is to provide the views of student's perception of the ideal organization for them. The paper also helps build the concept for Startup Company how attracts Gen Y. The paper will examine how influence employer branding toward intention to apply in e-commerce for Gen Y in Indonesia. The research uses 163 respondents who is last semester from some universities in Indonesia. To measure employer branding, the researcher uses a scale from anliacikdanalniacik (2012) that consist of 20 items and 9 items adopt from Tanwar and Prasad (2017). Researcher uses regression analysis for this research. The researcher finds that employer branding simultaneously influences toward Intention to apply. In partially,the study finds that only work-life in balance from all dimensions which influence toward intention to apply.
\end{abstract}

KEY WORDS: Employer Brand, E-Commerce\& Indonesia

Received: Feb 27, 2018; Accepted: Mar 17, 2018; Published: Mar 31, 2018; Paper Id.: IJBMRAPR20186

\section{INTRODUCTION \\ BACKGROUND}

In recent years, the issue of $\mathrm{Y}$ has been widely discussed in several theoretical studies and studies. In the workforce, Gen Y began to entry and the number rapidly increase while Baby boomers began to retire and the number starts to decrease (Anantamula \& Shrivastav, 2012). Gen Y wants a challenge, ambitious, trying to do it differently and self-oriented. In a work environment, they start not oriented towards a career that gives big salaries and bonuses. Gen Y has characteristics like creative, carefree, and risk-risk taker (Naim \& Usha, 2016). Gen Y prefers a more flexible job and naturally can switch their job easily. Gen Y wants to work with autonomy, rewards, and variety, and selfdevelopment to grow in the future for the need of self-esteem and self-actualization (Martin, 2005). Learning and development opportunities are a priority for Gen Y to ensure their career (Naim \& Usha, 2016).

Today, competition from employers in the Indonesia labor market is interesting. While a growing startup in Indonesia, large companies in Indonesia is rapidly responding to changes to compete against startups in the labor market. They began to set workplace and interesting environment matching for Millennial (Gen Y) like the startup. These conditions make the competition in the struggle for the best talent in a market more aggressively. Based on the 
survey conducted Universum (hrinasia.com), some big companies especially state-owned companies or local companies and public's service are considered the best employer in Indonesia. Bank Indonesia, Finance Ministry, and Pertamina become the best employer 2017 based on the survey. Different within Indonesia, IT companies dominate in attractive global employers like Google, Apple, Microsoft, and IBM. Based on global Universum, Google is the world's most attractive employers 2017.The second position is Goldman Sachs and the third is Apple. Companies in banking and investment industry, management consulting, and oil and gas now are considered less attractive for the job seeker.

The increasing foreign investment in IT Startup Company in Indonesia opened more job opportunities in the sector. Of course, the startup company becomes the new player in obtaining a potential candidate in the labor market. Based on the report from AT Kearney and Google, foreign investment in Indonesia for startup based technology is about USD\$ 3 billion in 2017. The number significantly increases from 2012 about USD \$ 44 million (id.technesia.com). Ecommerce and transport categories startup heavily dominate in the investment. The condition is caused how internet penetration in Indonesia continually increases each year. Based on a survey in 2016 that conduct with AsosiasiPenyelenggaraJasa Internet Indonesia (APJII) or Indonesia Internet Service Provider Association, Indonesia's internet user is about 132,7 million people (34.9\% from the total population). The number is higher than 2014 APJII Survey that is 88 million people internet users in Indonesia (34.89\%). The condition is responded by business and entrepreneur to catch this opportunity for this market potential. The internet changes consumer's behavior in daily activities that make increase the potential, the market of online business. The potential of market also attracts for the investor to entry in IT Startup business in Indonesia. Finally, professional employee or human resource will support them to continuously develop in future.

E-commerce has potential to expand more in Indonesia. E-commerce in Indonesia receives almost 58\% from the total foreign fund to Indonesia. Market size of internet retailing in Indonesia achieves about USD 3,490.5 million in 2017 and will increase about USD \$ 7,070 million in 2020 and USD \$ 11.101 million in 2020 (euromonitor.com). The number is higher than Malaysia (USD \$ 1,156.4 million), Vietnam (USD 1,148.6 million), Thailand (USD \$ 1,838.1 million), Singapore (USD 1,253.1 million), and the Philippines (USD \$ 227.3 million). The biggest market share of internet retailing is held by Alibaba Group Holding Ltd hold about $15.6 \%$. The number is too low as a market leader in the internet retailing industry. In the second, Salim Group holds about $7.4 \%$ from total market. E-Commerce competition still remains the chance to expand in this market.

The competition in the labor market to get the best talent encourages an organization to understand the importance of employer branding. The organization needs to manage its image to maximize recruiting effectiveness and attract job seeker or applicant (Lievens \& Highhouse, 2003) (Alniacik \& Anliacik, 2012). Organization needs to effectively communicate with job seekers and attract them to apply (Priyadarshini, Mamidenna, \& Sayeed, 2016). A previous research also proves that organization's image as an employer is a strong predictor of applicant' attraction (Turban, Forret, \& Hendrickson, 1998). For Gen Y, organization branding and image influenced to intention to join with an organization (Warmerdam, Lewis, \& Banks, 2015). They will judge the organization and create a decision to apply or to join. Organization's image as an employer becomes a strong predictor of applicant's attraction (Turban, Forret, \& Hendrickson, 1998). For Gen Y, organization branding and image influenced to intention to join with an organization (Warmerdam, Lewis, \& Banks, 2015). They will judge the organization and create a decision to apply or to join. Millennial has also focused on their work values which is very important for them to career's decision and career choice (Kuron, Lyons, 
Schweitzer, \& $\mathrm{Ng}, 2015)$.The objective of this paper is to provide the views of student's perception, especially Generation $\mathrm{Y}$ for the ideal organization for them. The paper will examine how influence employer branding toward intention to apply for Gen $\mathrm{Y}$ in e-commerce companies in Indonesia. The paper also helps build the concept for e-commerce companies how to attract Generation Y from Student while some big companies in Indonesia also target them.

\section{THEORITICAL BACKGROUND}

Zoomers, Gen X dan Gen Y. Zoomers in the workforce began to decrease and replace with next generation (Gen X $\&$ Gen Y). Many companies start to retire the old worker because of the nonproductive category. While Gen Y has ready replaced Baby Boomers who have retired. Baby Boomers was born in 1946-1960, Generation X was born in 1961-1981 and Gen Y was born after 1981 (Brosdahl and Carpenter's, 2011 quoted from Bolton et al. (2013)). Basically, nothing generation is the best of all generations. Gen $\mathrm{Y}$ is a generation that grew amid rapid advances in information technology. The condition causes them very expert in using technology. This generation is also renowned naturally creative and innovative. Different from other generation in personality, and motivator, Gen Y easily switch jobs frequently to catch opportunities for their need and they ignore job security (Naim \& Usha, 2016).

Generations Zoomer, $\mathrm{X}$, and $\mathrm{Y}$ have their own views on motivation. If Zoomer and generation $\mathrm{X}$ fear with a threat of work termination, but it cannot work for Generation Y (Cran, 2014). Gen Y can easily leave from an organization that is considered unfit for them. Gen Y motivate by self-development like learning and challenge (Naim \& Usha, 2016). Gen Y concern with their career and future prospect. Gen Y is motivated by friendly and comfortable leadership (Cran, 2014). They focus on how to earn money in an easy way (Cran, 2014). They love activities that are done together like sports activities together (Cran, 2014). They are very happy when they receive gifted as a reward. They also like charity and environmental improvement activities (Cran, 2014).

Employer branding. Employer branding is an application of the marketing principles of human resource management (Caple\& Turban, 2001). Employer defines the steadily designed and executed process of developing and maintaining the good reputation of the company with its basic component through sending the signals to stakeholders through the behavior, communication and imagery using the corporate identity (Jamshed, 2016). Sullivian (2004) defined employer branding as "a targeted, long -term strategy to manage awareness and perception of employees, potential employees, and related stakeholders with regard to a particular firm" (Alniacik \& Anliacik, 2012). Employer branding is a method for a company to attract high potential talent in the labor market. Organizations must try to make the different than competitors and to be seen as attractive employers for the prospective applicant or current employees (Lievens \& Highhouse, 2003). Employer branding can also be considered with an effort of companies to communicate to existing employee or candidate about them as a great place to work (Berthon, Ewing, \& Hah, 2005). Employer attractiveness is an antecedent the more general concept of employer brand. Employer attractiveness defined as the envisioned benefit that a potential sees in working for a specific organization (Berthon, Ewing, \& Hah, 2005). The more attractive an employer, the stronger employer brand equity.

Berthonatl al(2005) has developed the scale that called Employer Attractiveness (EmpAt) Scale with 25 items to identify the factors associated with employer brand form potential employee's perspective (student). Berthonat al(2005) divide the scale with five factors: interest value, social value, Economic value, development value, application value. Berthonat al. Absorbed from three dimensions from Ambler and Barrow (1996). Alniacik and Alniacik (2012) also 
developed the scale that is different with berthon at al (2005). Alniacik and alniacik (2012) constructed the employer attractiveness scale with six factors and 20 items. The factors consist of social value, market value, economic value, application, value, cooperation value, and workplace environment. Like Berthon at al. (2005), Alniacik and alniacik (2012) also used the student or potential employee to validate the scale. Tanwar\& Prasad (2017) developed the employer branding scale with 23 items with three -factor; healthy work atmosphere, training \& development, Work-Life in Balance, Ethics \& Corporate Social Responsibility, and Compensation and Benefit (Tanwar \& Prasad, 2017). Tanwarand Prasad (2017) assesses IT employees to validate the scale. Employer attractiveness significantly influence the applicant's intention to apply (Saini, Rai, \& Chaudhary, 2014). The research also confirms previous research conducted with Collin and steven (2002), or Agrawal and Swaroop (2009). According to Gomes and Neves (2011) organizational attractiveness takes a key role in explaining the process that leads intention to Apply.

\section{METHODOLOGICAL METHOD}

The researcher uses online-questionnaires. The researcher uses purposive sampling. The sample is a student or job seeker with age about 19-36 years old because the age is Generation Y (Millennial) who born 1981-1999 (McKinsey Report). The questionnaires will distribute to students from some universities in Indonesia that recognize the best universities like University of Indonesia, Bandung Technology Institute, Gajah Mada University, Bogor Agriculture University, and others. Why is a student? Students are considered as a job seeker in the near future and potential employees for the organization (Sivertzen, Nilsen, \& Olafsen, 2013). The research uses one independent variable which is an employer branding and intention to apply as a dependent variable. The respondent will ask to respond each statement in the questionnaires based their opinion about e-commerce companies in Indonesia. For analyzing data, the researcher conducts t-test (ANOVA) and regression analysis.

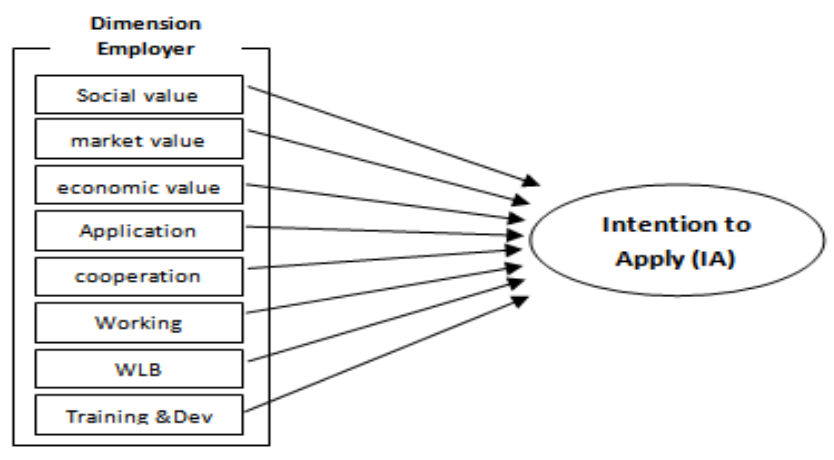

Figure 1: Research Model

Employer Branding. To measure employer branding, the researcher uses a scale from anliacikdanalniacik (2012) that consist of 20 items and 9 items adopt from Tanwar and Prasad (2017). From this source, the researcher will divide to 5 factors (social value, market value, economic value, application, value, cooperation value, and working environment) from anliacik\&alniacik (2012) and two factors (work-life balance and training and development) from Tanwar and Prasad (2017). Responses are taken by Likert type five- point where $1=$ strongly disagree and $7=$ strongly agree (Saini, Rai, \& Chaudhary, 2014). The respondent will ask "give your opinion about each these statement related e-commerce companies in Indonesia as employer organization.". To measuring intention to apply, the researcher use scale developed by Highhouse, Lieven, and Sinar (2003). The scale consists of 5 items. 1= strongly disagree, $5=$ strongly agree (Highhouse, Lievens, \& Sinar, 2003). Based on validity test, all items are valid because of the value of Kaiser-Meyer-Olkin (KMO) test 
$\geq 0.5$ and loading factor in component matrix $\geq 0.5$. All the items also considered reliable because of Conbach Alpha more than 0.6 and the value of corrected item $\geq 0.3$.

Table 1: Measurement Item in Each Variable

\begin{tabular}{|c|c|c|c|}
\hline Variable & Dimension & Questions & Item \\
\hline \multirow{29}{*}{$\begin{array}{c}\text { Employer Branding } \\
\text { (anliacik\&alniacik, } \\
\text { 2012) } \\
\text { Tanwar\& Prasad, } \\
\text { 2017) }\end{array}$} & \multirow{8}{*}{ Social Value } & Gaining career-enhancing experience & SV1 \\
\hline & & $\begin{array}{c}\text { Feeling good about yourself as a result of working } \\
\text { for the organization }\end{array}$ & SV2 \\
\hline & & Acceptance and belonging & SV3 \\
\hline & & Having a good relationship with your superiors & SV4 \\
\hline & & $\begin{array}{l}\text { The organization both values and makes use of your } \\
\text { creativity }\end{array}$ & SV5 \\
\hline & & $\begin{array}{l}\text { Good promotion opportunities within the } \\
\text { organization }\end{array}$ & SV6 \\
\hline & & Recognition/appreciation from management & SV7 \\
\hline & & Job security within the organization & SV8 \\
\hline & \multirow{4}{*}{ Market Value } & $\begin{array}{l}\text { The organization produces innovative products and } \\
\text { services }\end{array}$ & MV1 \\
\hline & & $\begin{array}{l}\text { The organization produces high-quality products and } \\
\text { services }\end{array}$ & MV2 \\
\hline & & $\begin{array}{c}\text { Opportunity to apply what was learned at a tertiary } \\
\text { institution }\end{array}$ & MV3 \\
\hline & & The organization is customer-orientated & MV4 \\
\hline & \multirow{2}{*}{ Economic Value } & An above average basic salary & EV1 \\
\hline & & An attractive overall compensation package & EV2 \\
\hline & \multirow{2}{*}{ Application Value } & Humanitarian organization gives back to society & AP1 \\
\hline & & Opportunity to teach others what you have learned & AP2 \\
\hline & \multirow{2}{*}{ Cooperation Value } & Hands-on inter-departmental experience & CV1 \\
\hline & & Supportive and encouraging colleagues & $\mathrm{CV} 2$ \\
\hline & \multirow{2}{*}{ Work Environment } & A fun working environment & WE1 \\
\hline & & Working in an exciting environment & WE2 \\
\hline & \multirow{6}{*}{$\begin{array}{l}\text { Training and } \\
\text { Development }\end{array}$} & My organization provides us online training courses & TR1 \\
\hline & & $\begin{array}{l}\text { My organization organizes various conferences, } \\
\text { workshops and training programs on regular basis }\end{array}$ & TR2 \\
\hline & & $\begin{array}{l}\text { My organization offers opportunities to work on } \\
\text { foreign projects }\end{array}$ & TR3 \\
\hline & & $\begin{array}{c}\text { My organization invests heavily in training and } \\
\text { development of its employees }\end{array}$ & TR4 \\
\hline & & $\begin{array}{c}\text { Skill development is a continuous process in my } \\
\text { organization }\end{array}$ & TR5 \\
\hline & & $\begin{array}{l}\text { My organization communicates clear advancement } \\
\text { path for its employees }\end{array}$ & TR6 \\
\hline & \multirow{3}{*}{ Work-Life Balance } & My organization provides flexible-working hours. & WL1 \\
\hline & & $\begin{array}{l}\begin{array}{l}\text { My organization offers opportunity to work from } \\
\text { home. }\end{array} \\
\text { hol }\end{array}$ & WL2 \\
\hline & & My organization provides on-site sports facility. & WL3 \\
\hline \multirow{5}{*}{$\begin{array}{c}\text { Intention to Apply } \\
\text { Highhouseat.al, } \\
\text { 2003). }\end{array}$} & & I would accept a job offer from the startup company. & IA1 \\
\hline & & $\begin{array}{l}\text { I would make the startup company one of my first } \\
\text { choice as an employer. }\end{array}$ & IA 2 \\
\hline & & $\begin{array}{l}\text { If the startup company invited me for a job interview, } \\
\text { I would go. }\end{array}$ & IA 3 \\
\hline & & $\begin{array}{l}\text { I would exert a great deal of effort to work for startup } \\
\text { company. }\end{array}$ & IA4 \\
\hline & & $\begin{array}{l}\text { I would recommend the startup company to a friend } \\
\text { looking for a job. }\end{array}$ & IA5 \\
\hline
\end{tabular}




\section{ANALYZE AND FINDINGS}

From total received questionnaires (180 respondents), only 163 can process to the next step. From received data, based on gender, respondents consist of 35\% male and $65 \%$ female. Based on GPA, respondents consists of $4,9 \%$ GPA lower than 3.25, 38\% GPA 3.35-3.50, and 57.1\% GPA higher than 3.50. Based on work experience, 30,7\% respondents don't have work experience and $69.3 \%$ respondents have work experience. All respondents are Generation Y or born in 1981-1999.

\section{Descriptive Analysis}

From the descriptive analysis, Social value and work environment are the highest means score that is considered by respondent as the most appropriate factor with e-commerce attribute as an employer. Based on data, all employer branding factors are considered in accordance with the attributes of e-commerce companies in Indonesia. In Social Value, item SV5 becomes the highest mean score in social value factor. In market Value, item MV1 becomes highest mean score in market Value factor. In Economic Value, item EV1 becomes highest mean score in Economic Value factor. In Application Value, item AP1 becomes highest mean score in Application Value factor. In Cooperation Value, item CV2 becomes highest mean score in Cooperation Value factor. In Work environment, item WE2 becomes highest mean score in Work environment factor. In training and development, item TR5 becomes highest mean score in training and development factor. In Work-life in Balance, item WL1 becomes highest mean score in Work-life in Balance factor. A dimension of Work, Environment has the highest score of the grand mean (6.321). Respondents consider that work environment is the most attractive factor for e-commerce company's attribute. The grand mean for the work environment (6.321) and social value (6.1074) is higher than the economic value (5.990). The grand mean of Intention to apply is 5.20 that define as amajority of respondents have interested to apply in e-commerce companies in Indonesia.

Table 3: Descriptive Analysis

\begin{tabular}{|c|c|c|c|}
\hline Dimension & Mean & S.D & Std. Error \\
\hline Social Value & 6.1074 & 0.84561 & 0.06623 \\
\hline Economic Value & 5.9908 & 1.01451 & 0.07946 \\
\hline Market Value & 5.9816 & 0.87953 & 0.06889 \\
\hline Cooperation Value & 6.0000 & 0.98914 & 0.07748 \\
\hline Aplication Value & 5.8221 & 1.04628 & 0.08195 \\
\hline Work Environment & $6.3221 *$ & 0.91064 & 0.07133 \\
\hline Training and Development & 5.8630 & 0.92813 & 0.07270 \\
\hline Work Live in Balance & 5.6769 & 1.04128 & 0.08156 \\
\hline Employer Branding & 5,9746 & 0.75215 & 0.05891 \\
\hline Intention to Apply & 5.2012 & 1.15267 & 0.09028 \\
\hline
\end{tabular}

Note: *) the highest score

\section{Multiple Regressions}

From F-test obtained F-value about 3.903 with a probability of 0.00 or smaller than $0.05(p<0.05)$. Therefore it can be concluded that social value (SV), market value (MV), economic value (EV), application, value (AP), cooperation value (CV), training (TR), work environment (WE), and work-life balance (WLB)influence simultaneous toward the intention to apply (IA) to e-commerce companies . In partially, only work-life in balance (WLB) has significant influenced toward intention to apply (IA) (Sign $(0.041<0.05)$. Social value (SV), market value (MV), economic value (EV), application, value (AP), cooperation value (CV), training (TR), work environment (WE) don't partially influence toward 
intention to apply (IA). The relationship between work-life in balance and intention to apply is a positive relationship.

Table 4: Regression Analysis

\begin{tabular}{|c|c|c|c|c|c|}
\hline Costant & $\begin{array}{c}\text { Under standardized } \\
\text { Coefficients }\end{array}$ & $\begin{array}{c}\text { Standardized } \\
\text { Coefficients }\end{array}$ & Sig. & $\begin{array}{c}\text { Expected } \\
\text { Sign }\end{array}$ & Con. \\
\hline SV-IA & 10,718 & & & & \\
\hline MV-IA & 0,004 & 0,121 & 0,977 & + & Not confirm \\
\hline EV-IA & $-0,014$ & $-0,008$ & 0,939 & + & Not confirm \\
\hline CV-IA & 0,197 & 0,069 & 0,542 & + & Not confirm \\
\hline AP-IA & 0,010 & 0,003 & 0,979 & + & Not confirm \\
\hline WE-IA & $-0,110$ & $-0,040$ & 0,740 & + & Not confirm \\
\hline TR-IA & $-0,970$ & $-0,031$ & 0,807 & + & Not confirm \\
\hline WLB-IA & 0,268 & 0,259 & 0,052 & + & Not confirm \\
\hline
\end{tabular}

Note: significance $p<0.05^{*}$

\section{DISSCUSSIONS}

The study indicates that the employer branding influence toward intention to apply for Generation $\mathrm{Y}$ in ecommerce branding. Employer branding can be considered with effort by companies to communicate to existing employee or potential candidate about them as a great place to work (Berthon, Ewing, \& Hah, 2005). Basically, when the applicant will apply for a job, they will search information about the organization. The lack information about the organization will stop them to apply because they will not interest with the unfamiliar organization (Drury, 2016).

Surprisingly, only work life in balance as employer branding dimension in e-commerce that influences intention to apply from students and job seekers who are Generation Y's. They consider that e-commerce as one of the attractive organizations to give work-life in balance condition. They consider that e-commerce provides flexible working time to the employee. It relates how Generation Y tend to pursue a freedom, sociable, and values home (family) (Hurst \& Good, 2009) (Rani \& Samuel, 2008)and they want to keep between work and life, willing to work at anytime and in any place (Anantatmula \& Shrivastav, 2013). They need their time to do, they want and find the meaning of their life.

Although this research cannot show the relationship between social value and intention apply in Gen $\mathrm{Y}$ to ecommerce companies, the companies should take attention for the social aspect. They respect with constructive feedback from their supervisors or colleagues (Anantamula \& Shrivastav, 2012) (Hurst \& Good, 2009). They are likely to enjoy when they can contribute more to an employer organizations. They will appreciate if they participate in the important decision for an organization (Hurst \& Good, 2009).

The research shows how economic value doesn't influence in intention to apply to e-commerce companies for Generation Y's. Generation Y's is not money oriented generation because of they likely to motivate with how contributing to society, parenting well, and balance life (Hurst \& Good, 2009). For Generation Y, money can motivate them to join to the organization or make performance well. E-commerce companies actually offer a competitive salary than other industries. Based on the 2017 Salary Survey conducted Kelly service, oil and gas companies and financial service still be top paying industries. After the industries, High Tech, infrastructure and FMCG is the next of the top paying industries.

The study cannot show the relationship between Application Value and intention to apply in Generation Y's for ecommerce companies. In literature context, application side is one of the most attractive attributes from an organization for 
Gen Y. Generation Y interest with the organization with a high contribution to society (Hurst \& Good, 2009). Generation $\mathrm{Y}$ will prefer to do more valuable work for the lives of many people. They will appreciate the impact of their work on the world.

The study cannot show the relationship between cooperation value and intention to apply in Generation Y's for ecommerce companies. In some literature, cooperation is one of the factors that attract and retain Generation Y. Generation Y prefers conduct task with teamwork. Generation Y's seek leader who respects with them, including their opinion and view about a problem, listen to them and appreciate their opinion (Rani \& Samuel, 2008).

The study cannot show the relationship between work environment and intention to apply in Generation Y's for ecommerce companies. The e-commerce companies are not considered the only company that provides a comfortable working environment. Companies from other industries have also offered as well as e-commerce companies. The organization must focus on how to create a fun and exciting atmosphere (Rani \& Samuel, 2008). A fun workplace will impact to better productivity. Gen Y cares to pursue fun at work. The top management's role can attract and retain Gen Y in creating a fun work environment because Generation Y is fun-motivated tribe (Choi \& Kwon, 2013).

In the last, the study cannot explain the relationship between training and development aspect and intention to apply in Generation Y's for e-commerce companies. In aspect training and development, Generation Y's need a challenging job and involving greater responsibility (Rani \& Samuel, 2008). They want to learn more and focus on selfdevelopment.

\section{MANAGERIAL IMPLICATION}

According, Robert Walters, some companies in Indonesia will face shortage talent especially for local talent. In other side, retaining and recruiting necessary talent become the challenge in 2017 . The condition encourages an organization to create efficient recruitment process to meet the best talent. The challenge also faces with e-commerce companies. They must compete with other industries to obtain potential candidate in the labor market. They will not easily compete with big companies in other sectors (industries) in Indonesia.

Actually, e-commerce becomes the highest position in industries expecting strong growth categories (Kelly Service). Therefore, the study indicates how the importance employer branding component for improving potential applicant (candidate) perceptions of the company. Their knowledge about an organization may influence their decision to apply in a recruitment process. The more applicants in the recruitment process, the greater chances of the company getting potential talent.

HR should continue to prepare specific strategies to build strong employer branding in the job seekers' minds. Ecommerce companies can increase the media to communicate e-commerce companies as a great workplace for Generation Y. The media are YouTube channel for work condition, an opportunity for the internship, and company visit for a student. E-commerce can also make a video for the recruitment process that attracts more applicants. The video should focus the strength of e-commerce companies as an employer with providing work-life in balance.

E-commerce companies can show in employer branding dimension appropriate with Generation Y (social value, market value, economic value, application value. Although all of employer branding dimension is important, the company can more focus on work-life balance than other (based in the study). The company confirms that only e-commerce that secures the balancing their life (Gen Y). The company can inform a flexible working time, interested reward (e.g. vacation 
time, free travel package, and other) and facilities to increase their quality of life (e.g. creative rooms, sleep room, sports room, and other).

\section{CONCLUSIONS}

The result of study shows how employer branding simultaneously influences toward intention to apply for Generation $\mathrm{Y}$ in e-commerce companies. The study encourages the e-commerce company to more care in employer branding for attracting and retaining Generation $\mathrm{Y}$ (talent). In the last, e-commerce companies should communicate to the potential applicant (candidate) if they are the great place to work for attracting Gen Y. Employer branding becomes a competitive advantage to compete in the labor market. In partially, the study can indicate that work-life in balance influences toward intention to apply. The other dimension cannot indicate the relationship with intention to apply. Based on the result, the e-commerce company can more focus on work-life balance than other (based in thestudy). The company confirms that only e-commerce that secures the balancing their life (Gen Y).

\section{LIMITION OF STUDIES}

The research only uses two variables consist of intention to apply as the dependent variable and employer branding as an independent variable. In future, the other researcher can use other variables that can explain more intention to apply, example: job attributes, organizational culture, and other. The portion of a sample from each university is not balanced.The condition will become less accommodate each university.

\section{REFERENCES}

1. Alniacik, E., \& Anliacik, U. (2012). Identifying dimensions of attractiveness in employer branding: effects of age, gender, and current employement status. Procedia-social and behaviorial Science, 1336-1343.

2. Anantamula, V. S., \& Shrivastav, B. (2012). Evolution of project teams for generation Y workforce. International Journal of Managing project in Business, Vol. 5 Issue 1, 9-26.

3. Anantatmula, V. S., \& Shrivastav, B. (2013). Evolution of project teams for Generation Y workforce. Journal of Service Management, Vol 24 Issue 3, 245-267.

4. Berthon, P., Ewing, M., \& Hah, L. L. (2005). Captivating company: Dimensions of attractiveness. International Journal of Advertising, 151-172.

5. Choi, Y. G., \& Kwon, J. (2013). Effect of attitudes vs experience of workplace fun on employee behaviors: focus on Generation Y in hospitality industry. Education + Training, Vol 55 Issue 3, 272-290.

6. Gomes, D., \& Neves, J. (2011). Organizational Attractiveness and prospective applicant' intention to apply. Personel Rievew, Vol 40 Issue 6, 684-699.

7. Highhouse, S., Lievens, F., \& Sinar, E. F. (2003). Measuring attraction to organization. Educational and Psychological Measurement, Vol 63 No 6, 986-1001.

8. HYPERLINK"https://economictimes.indiatimes.com/jobs/google-worlds-most-attractive-employersurvey/articleshow/6651574.cms"https://economictimes.indiatimes.com/jobs/google-worlds-most-attractive-employersurvey/articleshow/6651574.cms

9. HYPERLINK"https://www.forbes.com/sites/jeffkauflin/2017/06/30/the-most-attractive-employers-for-business-studentsaround-the-world-in-2017/" V "1616e03fd268" https://www.forbes.com/sites/jeffkauflin/2017/06/30/the-most-attractiveemployers-for-business-students-around-the-world-in-2017/\#1616e03fd268 
10. HYPERLINK "https://universumglobal.com/worlds-most-attractive-employers-2017/" https://universumglobal.com/worldsmost-attractive-employers-2017/

11. Hurst, J. L., \& Good, L. K. (2009). Generation Y and career choice: the impact of retail career perceptions, expectations and entitlement perceptions. Career Development International, Vol 12 Issue 6, 504-522.

12. Jamshed, H. G. (2016). An exploratory on the impact of recruitment process outsourcing on employer branding of an organization. Strategic Outsourcing: An Interntational Journal, Vol 9 Issue 3, 303-323.

13. Kreitner, R., \& Kinicki, A. (2003). Organizational Behavior. New York: McGraw-Hill Higer Education.

14. Kuron, L. K., Lyons, S. T., Schweitzer, L., \& Ng, E. S. (2015). Millenials's work values: differences across th school to work transition. Personal Review, Vol 44 Issue 6, 991-1009.

15. Lievens, F., \& Highhouse, S. (2003). The relation of instrumental an symbolic attribute to a company's attractiveness as an employer. Personnel Psychology, 75-102.

16. Lim, H. L. (2012). Generation Y workforce expectation: implications for the UEA. Education, Business and Sociey: Contemporaty Middle Eastern Issues, Vol 5 Issue 4, 281-293.

17. Martin, C. (2005). From high maintenance to high productivity: what manager need to know about generation Y. Industrial and Commercial Training, Vol 37 No 1, 39-44.

18. Naim, M. F., \& Usha, L. (2016). Knowledge sharing as an intervention for gen Y emloyees' intention to stay. Industrial and Commercial Training, Vol. 48 Issue 3, 142-148.

19. Pierce, J. L., \& Gardner, D. G. (2004). Self-esteem within the work and organizational context: a review of the organizationbased self-esteem literature. Journal of Management, 591-622.

20. Priyadarshini, C., Mamidenna, S., \& Sayeed, O. B. (2016). Identifying dimensions of employer attractiveness in Indian Universities; an approach toward scale development. Journal of Asia Business Studies, Vol 10 Issue 2, 183-193.

21. Rani, N., \& Samuel, A. (2008). A study on generational differences in work values and person-organizational fit and its effect on turnover intention of Generation Y in India. Journal of Managerial Psychology, Vol 23 Issue 8, 891-906.

22. Saini, G. K., Rai, P., \& Chaudhary, M. K. (2014). What do best employer survey reveal about employer branding and intention to apply. Journal of Brand Management, Vol 21 Issue 2, 95-111.

23. Sivertzen, A.-M., Nilsen, E. R., \& Olafsen, A. H. (2013). Employer branding: employer attractiveness and the use of social media. Journal of Product \& Brand Management, Vol 22 Issue 7, 473-483.

24. Tanwar, K., \& Prasad, A. (2017). Employer brand scale development and validation: a second order factor approach. Personnel Review, Vol 46 Issue 2, 389-409.

25. Terjesen, S., Vinnicombe, S., \& Freeman, C. (2007). Attracting Generation Y graduates: organizational attributes, likehood to apply and sex differences. Career Developmental International, Vol 12 Issue 6, 504-522.

26. Twenge, J. M., Campbell, S. M., Hoffman, B. J., \& Lance, C. E. (2010). Generational differences in work values: leisure and extrinsic values increasing, social and intrinsic values decreasing. Jornal of Management, Vol 36 No 5, 1117-1142.

27. Warmerdam, A., Lewis, I., \& Banks, T. (2015). Gen Y recruitment: understanding graduate intention to join an organization using theory of planned behavior. Education + Training, Vol. 57 No. 5, 560-574 